\title{
COLLABORATIVE LEARNING TO IMPROVE PRESERVICE TEACHERS' KNOWLEDGE ABOUT CHEMISTRY CONTENT IN THE AUTOMOTIVE VOCATIONAL CONTEXT
}

\author{
Antuni Wiyarsi ${ }^{1}$, Sumar Hendayana ${ }^{2}$, Harry Firman ${ }^{2}$, dan Sjaeful Anwar ${ }^{2}$ \\ ${ }^{1}$ FMIPA Universitas Negeri Yogyakarta, ${ }^{2}$ FPMIPA Universitas Pendidikan Indonesia \\ email: antuni_w@uny.ac.id
}

\begin{abstract}
This study was aimed to examine the effectiveness of collaborative problem-solving-based learning to improve knowledge about chemistry content in the automotive vocational context. The study design used was one-group pretest-posttest design and applied to Vocational Chemistry subjects. Data analysis was performed by using the normalized gain-test formula and t-test using SPSS software version 21. The findings showed that collaborative learning is effective to improve pre-service teachers' knowledge about chemistry content of petroleum and polymer chemistry. The mastery level of basic knowledge about the petroleum and polymers is fairly good. However, the knowledge of the content of petroleum and polymer applications in the automotive field is not satisfactory. Although the application content knowledge increased with the moderate criterion for the application of petroleum and with the low criterion for polymer applications, the mastery level of pre-service teachers at the end of the course was still low. Factors that allegedly become the causes of the low mastery of application content knowledge are the characteristic factor of the content, conceptual learning difficulties and the experience factor.
\end{abstract}

Keywords: content knowledge, chemistry in the vocational context, preservice chemistry teachers, petroleum, polymers

\section{PEMBELAJARAN KOLABORATIF UNTUK MENINGKATKAN PENGETAHUAN KONTEN KIMIA KONTEKS KEJURUAN OTOMOTIF CALON GURU KIMIA}

\begin{abstract}
Abstrak: Penelitian ini bertujuan untuk mengkaji efektivitas pembelajaran kolaboratif berbasis pemecahan masalah dalam meningkatkan pengetahuan konten kimia konteks kejuruan otomotif. Desain penelitian yang digunakan adalah one group pretes-postes design dan diterapkan pada mata kuliah Kimia SMK. Analisis data dilakukan denganuji t menggunakan software SPPS edisi 21 dengan menggunakan rumus gain-test yang dinormalisasi. Hasil penelitian menunjukkan bahwa pembelajaran kolaboratif efektif dalam meningkatkan pengetahuan konten minyak bumi dan polimer bagi mahasiswa calon guru kimia. Tingkat penguasaan pengetahuan dasar tentang minyak bumi dan polimer cukup baik. Namun, untuk pengetahuan konten aplikasi minyak bumi dan polimer dalam bidang otomotif belum memberikan hasil yang menggembirakan. Meskipun pengetahuan konten aplikasi tersebut meningkat dengan kriteria peningkatan sedang untuk aplikasi minyak bumi dan kriteria rendah untuk aplikasi polimer, tingkat penguasaan calon guru di akhir perkuliahan masih rendah. Faktor yang diduga menjadi penyebab rendahnya penguasaan pengetahuan konten aplikasi ini adalah faktor karakteristik konten, kesulitan belajar konseptual, dan faktor pengalaman.
\end{abstract}

Kata Kunci:pengetahuan konten, kimia konteks kejuruan, calon guru kimia, minyak bumi, polimer

\section{INTRODUCTION}

The teacher education program is the starting point to create qualified teachers. The improvement of chemistry teacher quality becomes the major focus on the issue of the low quality of science education. Studies showed 
that the quality of teachers is the most important contributing factor in the success of student learning (Khasawneh et al, 2008; Rohaan et al, 2009; Adodo and Gbore, 2012; Karaman, 2012). This teacher quality is linked to the competencies that must be owned by a chemistry teacher to implement effective learning.

The description of competences that chemistry teachers must possess in Indonesia has been stated in Government Regulation number 74 year 2008. Article 3 Clause 2 states that the teacher Competences include the pedagogical competence, personal competence, social competence, and the professional competence. Professional competence is related to the teachers' ability to master the concepts, laws and theories of chemistry and their application in a flexible way, to understand the scope and depth of chemistry and to develop teaching learning materials creatively. This is in line with the recommendation of the National Science Teacher Association/NSTA (2003:4-30) related to competences that science teachers must possess, namely the mastery of academic content and basic science, inquiry capabilities, understanding of the curriculum and understanding of science issues. The term of content knowledge is used to conceptualize the teachers' professionalism in mastering the subject matter (Baumert et al, 2010:98). Content knowledge is the knowledge of facts and concepts specific to the subject matter. Good mastery of chemistry content knowledge becomes a strong foundation for teaching chemistry effectively.

Several studies have shown the importance of the teacher content knowledge to develop the quality of learning chemistry. The content knowledge has a positive influence on the effectiveness of teaching, becoming the key factor for the development of teachers' professionalism and is strongly correlated with the ability of teachers to teach appropriate chemistry (Ozden, 2008; Justi \& van Driel, 2005). The learning of chemistry content knowledge for pre-service chemistry teachers is provided globally in accordance with the hierarchy in scientific disciplines, such as Physical Chemistry, Organic Chemistry, or Analytical Chemistry. The che- mistry contents are mostly given in the form of basic concepts and pre-service teachers are not provided with chemistry content that they will teach, especially in the context of vocational schools.

The learning of specific chemistry content is required by pre-service teachers in order to have good readiness in teaching chemistry at a vocational school. The preparation of pre-service chemistry teachers appropriate for vocational school needs is required because of the presence of several different special professional abilities to be possessed by chemistry teachers in general schools and vocational schools. This is related to the characteristics of the chemistry content taught, chemistry learning objectives, and characteristics of vocational and general education programs (Khasawneh et al, 2008; Faraday et al., 2011). Chemistry content taught in vocational schools, if it is seen from the depth and breadth of the relative material is narrower than chemistry content in general secondary schools. However, one of the goals of chemistry subject in vocational schools is to support students' expertise competence. Thus, chemistry learning in vocational schools must be created and developed in such a way in order to fit and support the students' expertise. Learning about the specific content aspect that is appropriate for the context in which the content will be taught is very important for pre-service chemistry teachers, because most of teachers have limitation in transferring content due to their low mastery of concepts (Kapyla, et al., 2009; Dolfing, et al., 2012).

The implication of this is that pre-service chemistry teachers need a special in order that they are ready to teach chemistry in vocational schools, not only in general secondary schools. One of the teacher training institutions in Yogyakarta Special Province provides courses that specifically discuss the vocational school curriculum and the enrichment of chemistry materials needed in vocational schools. Given the breadth of expertise in vocational school programs and the limited course with only two credits, the content should be carefully selected. 
The criteria for the content given is based on a needs analysis of expertise, especially in vocational programs that are not directly related to chemistry but require good basic chemistry and that have not been accommodated fully in other subjects learned by pre-service chemistry teachers during their educational program.

In accordance with the paradigm of constructivism, the strategy adopted in learning chemistry specific content is supposed to be based on the activity of pre-service chemistry teachers to construct their knowledge independently. This is in accordance with the principles of adult learning. Courses given should help pre-service chemistry teachers to think critically about the material learned and pay attention to the difficulties in the conceptual and reasoning which may be experienced by students.

Collaborative learning is a teaching strategy based on the student activity. Collaborative learning strategy is highly recommended in chemistry education to improve students' learning activities (Arrington, et al., 2008:281). Collaborative learning can be described as a process of interaction in small groups in which several people help each other to achieve a goal collectively. The activity in collaborative learning is very broad, but more centered on student activities in exploring or developing applications of the learning content to develop reasoning, practicing the uses of higher order thinking skills and creating the knowledge (Barkley, et al., 2005).

This paper specifically examined the findings of research that aims to determine the increase of content knowledge of pre-service chemistry teachers in vocational chemistry subjects implementing collaborative learning. The content that is chosen for learning is chemistry content which is linked and appropriate to the automotive vocational context. Automotive Engineering Program itself is an expertise program that has the greatest number, as compared with any other expertise programs in vocational schools (DITPSMK, 2014:1). Automotive engineering is not the expertise included in the field of chemistry. It has a lot of expertise content related to and requires good basic chemistry understanding. Among them, chemistry is needed to understand the character of material (element or polymer), component and accessories of vehicles, how fuel and combustion occurs with a certain amount of energy, how the battery system works, the impact of a fuel combustion, the character of gas for welding and cooling systems, and so forth. Therefore, chemistry content that can be applied to this expertise should be given to pre-service chemistry teachers so that later on they will be able to teach chemistry at vocational schools effectively.

\section{METHOD}

The study design used was a one-group pretest-posttest design. Research subjects were 36 students Study Program of Chemistry Education joining the subject of Vocational Chemistry.

Collaborative learning is carried out in small groups of 3-4. Group formation is done randomly and is expected to be heterogeneous. The learning is conducted in five meetings with the content of petroleum (three meetings) and polymers (two meetings). The content selection is based on a content analysis of the chemistry content corresponding to the context of vocational automotive engineering. The chemistry content is in the form of problem application of polymers and petroleum in the automotive field. Students collaborate in groups to identify information, to raise the issue of the problem, to draw up hypotheses, to collect information resources, to provide alternative solutions and to write an article based on all the answers.

The instruments used to data collection of research was in the form of multiple choice tests given before and after the study. The validation of the instrument was done theoretically and empirically. The theoretical validation was done by experts involving seven chemists and chemical education from two different public universities. An analysis of the correspondence between the indicators and the items and the experts' opinion was conducted by performing a quantitative calculation. The calculation of the theoretical validation was done by calculating the value of the content validity ratio (CVR) 
Law for each item in the test (Wilson, et al., 2012: 199) with the formula as follows:

$$
\mathrm{CVR}=\frac{\mathrm{n}_{\mathrm{e}^{-}} \mathrm{N} / 2}{\mathrm{~N} / 2}
$$

$\mathrm{n}_{\mathrm{e}}$ indicates the number of experts who agreed and $\mathrm{N}$ refers to the number of experts who did the validation. The CVR value calculation results were then compared with the value of the CVR value table of Wilson at the significance level of $5 \%(\alpha=0,05)$. The CVR value for seven validators is 0.622 (Wilson, et al., 2012:199). The calculation shows that All the test item have CVR values greater than the value of the CVR table, so it can be said that theoretically it is valid. In addition, the correlation calculation results through Cronbach's Alpha were done for each component of chemistry content and are summarized in Table 1 .

Based on the calculation of each of these components, it can be concluded that there are five items whose validity is very low and these items were not included for the data collection. The gratings test of the chemistry content in the automotive vocational context is presented in Table 2.
Table 1. Reliability Analysis Results Summary

\begin{tabular}{|c|c|c|c|}
\hline $\begin{array}{l}\text { Component } \\
\text { of Content }\end{array}$ & $\begin{array}{c}\text { Total } \\
\text { of } \\
\text { Tests } \\
\text { Item }\end{array}$ & $\begin{array}{c}\text { alpha } \\
\text { cronbach's }\end{array}$ & $\begin{array}{c}\text { Numbers of } \\
\text { problem with } \\
\text { item correlation } \\
<0.3\end{array}$ \\
\hline KDMB & 5 & 0,610 & $2(0,05)$ \\
\hline APMB & 15 & 0,696 & $\begin{array}{l}12(-0,061) \\
15(-0,009)\end{array}$ \\
\hline KDP & 7 & 0,726 & None \\
\hline APP & 13 & 0,706 & $\begin{array}{c}28(0,124) \\
36(0,05)\end{array}$ \\
\hline
\end{tabular}

Based on the analysis results, it indicates that the test of content that was developed, as a whole, has Cronbach's Alpha coefficient of 0.878 at the significance level of 0.05 . It can be concluded that the test of content is valid and reliable soit can be used as an instrument for research data collection.

Based on the analysis results, it indicates that the test of content that was developed, as a whole, has Cronbach's Alpha coefficient of 0.878 at the significance level of 0.05 . It can be concluded that the test of content is valid and reliable so it can be used as an instrument for research data collection.

Table 2. Gratings Test of Chemistry in Automotive Vocational Context

\begin{tabular}{|c|c|c|c|c|c|}
\hline No. & Content & Component & Subcomponent & $\begin{array}{l}\text { Number of } \\
\text { Items }\end{array}$ & $\begin{array}{c}\text { Total Number } \\
\text { of Items }\end{array}$ \\
\hline \multirow{5}{*}{1} & \multirow{5}{*}{ Petroleum } & \multirow{2}{*}{$\begin{array}{l}\text { Basic Concept of Pe- } \\
\text { trolium }\end{array}$} & Fractination of Petrolium & 1,2 & 2 \\
\hline & & & $\begin{array}{l}\text { The impact of burning } \\
\text { petroleum fuels }\end{array}$ & 16,17 & 2 \\
\hline & & \multirow{3}{*}{$\begin{array}{l}\text { Aplication of Petroli- } \\
\text { um Fraction in the field } \\
\text { of Automotive }\end{array}$} & Gasoline & $3,4,5,6,7,8,9$ & 7 \\
\hline & & & Diesel fuel & $10,11,12$ & 3 \\
\hline & & & Lubricant & $13,14,15$ & 3 \\
\hline \multicolumn{2}{|c|}{ Subtotal 1} & & & & 17 \\
\hline \multirow{5}{*}{2} & \multirow{5}{*}{ Polymers } & \multirow{3}{*}{$\begin{array}{l}\text { Basic Concept of Poly- } \\
\text { mers }\end{array}$} & $\begin{array}{l}\text { Nature and classification } \\
\text { of polymers }\end{array}$ & $18,20,21,22$ & 4 \\
\hline & & & $\begin{array}{l}\text { Impact of the use of plastic } \\
\text { and rubber }\end{array}$ & $25,33,34$ & 3 \\
\hline & & & Vulcanitation of rubber & 19,23 & 2 \\
\hline & & \multirow{2}{*}{$\begin{array}{l}\text { Aplication of Polymers } \\
\text { in the field of automo- } \\
\text { tive }\end{array}$} & $\begin{array}{l}\text { Nature and classification } \\
\text { of plastic }\end{array}$ & $\begin{array}{l}26,27,28,29, \\
32,35\end{array}$ & 6 \\
\hline & & & $\begin{array}{l}\text { The use of rubber and } \\
\text { plastics in the automotive } \\
\text { field }\end{array}$ & $24,30,31$ & 3 \\
\hline \multicolumn{3}{|c|}{ Subtotal 2} & & & 18 \\
\hline \multicolumn{3}{|c|}{ Number of Problems } & & & 35 \\
\hline
\end{tabular}


The data analysis was performed by $\mathrm{t}$ test using SPSS software version 21. Second, to know the increase in chemistry content knowledge of vocational context of vocational automative field possessed by the students, both overall and within each content component, the data were analyzed using the formula, namely normalized gain-test, as follows:

$$
\begin{aligned}
& <g> \\
& =\frac{\text { score of posttest }- \text { score of pretest }}{\text { maximum score }- \text { score of pretest }}
\end{aligned}
$$

The increase of the concept mastery is based on the value $\langle\mathrm{g}\rangle$, with the following criteria:

$$
\begin{aligned}
& \text { High if }(\langle\mathrm{g}\rangle)>0.7 \\
& \text { Moderate if } 0.7 \geq(<\mathrm{g}\rangle) \geq 0.3 \\
& \text { Low if }(\langle\mathrm{g}\rangle)<0.3
\end{aligned}
$$

\section{FINDINGS AND DISCUSSION}

Analysis Results of the Difference in the Pretest and the Posttest of Chemistry Content Knowledge in the Vocational Context

The results of the analysis of the differences in the pretest and the posttest mean scores in the experimental group and in the control group are summarized in Table 3. In the experimental group the obtained $t$ value is -11.402 with the significance of 0.000 . This shows that there are differences in the pretest and the posttest mean scores in the chemistry knowledge of the vocational context of pre-service teachers in the experimental class, with higher posttest scores. The calculation result for the control class showed that the obtained $t$ value is -4.796 at the significance level of 0.00 . This result indicates that there is a significant difference between the knowledge of the vocational context of the preservice chemistry teachers in the control class before and after learning. In general, it can be stated that both in the experimental group and in the control group there was an increase in chemistry knowledge of the vocational context.

\section{Analysis Results of n-Gain of the Chemistry Knowledge in the Vocational Context as a Whole}

The results of the n-gain data analysis to know the extent of the increase in knowledge of chemistry content are summarized in Figure 1. According to the graph, the overall increase in pre-service teachers' mastery of the chemistry content of the vocational context is $=0.362$ and this belongs to the moderate criterion. The components of the content of the basic concepts of polymer (KDP) are the ones that have an average of the biggest $n$-gain, namely 0.4877 . The increase of the students' mastery of the content of petroleum applications (APMB) in the automotive field has the lowest mean of $n$-gain copared with other components. The n-gain is 0.291 and it belongs to the low category. Two other components, namely the basic concept of the content of petroleum (KDB) and polymer applications in the automotive field (APP) belong to the fair category.

The results on the increase of content knowledge are shown in the form of the mastery learning for every component (Table 4). The pre-test data show that the initial knowledge of the pre-service chemistry teachers was still low, lower than the ideal mean score. The initial knowledge for the basic concept component both in the content of petroleum and in the polymers is relatively higher than the mastery of the application content. The students' initial knowledge of the petroleum application content is still very low, only $20.3 \%$ of the ideal score. As for the polymers application content in the automotive field, the mastery percentage is

\begin{tabular}{|c|c|c|c|c|c|c|c|}
\hline & & Mean & $\mathrm{N}$ & Standard Deviation & $t$ count & $\mathrm{p}$ & Information \\
\hline \multirow[t]{2}{*}{ Experiment class } & Pre test & 11,50 & 36 & 2,63 & $\begin{array}{l}-11,402 \\
\end{array}$ & 0,000 & Difference \\
\hline & Post test & 20,17 & 36 & 3,92 & & & indicated \\
\hline \multirow[t]{2}{*}{ Control class } & Pre test & 10,22 & 23 & 1,51 & $-4,796$ & 0,000 & Difference \\
\hline & Post test & 12,30 & 23 & 2,22 & & & Indicated \\
\hline
\end{tabular}
higher $(37.7 \%)$. However, it still belongs to the low category.

Table 3. Test Results of Difference in Pretest and Posttest of Chemistry Knowledge in the Vocational Context 


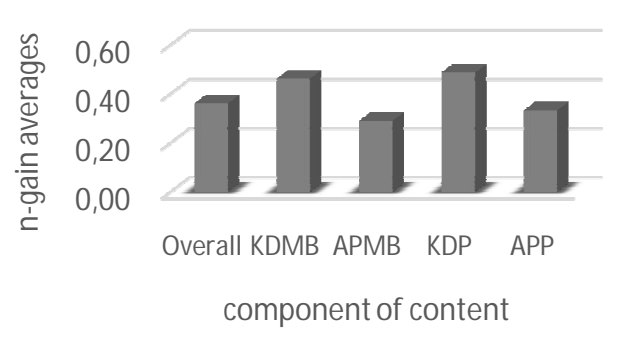

Figure 1. Average of n-Gain Content Mastery

Table 4. Percentage Mastery of Content Knowledge

\begin{tabular}{lll}
\hline \multirow{2}{*}{ Component } & \multicolumn{2}{l}{ Mastery Percentage (\%) } \\
\cline { 2 - 3 } & Pre-test & Post-test \\
\hline KDMB & 47,22 & 72,22 \\
APMB & 20,3 & 44,02 \\
KDP & 44,44 & 71,83 \\
APP & 37,37 & 59,34 \\
Mean & 37,3325 & 61,8525 \\
\hline
\end{tabular}

After following up collaborative learning, the percentage of content mastery owned by the overall pre-service chemistry teachers experience an increase. Results of the post-test show that the mastery of chemistry content for basic concept of petroleum or polymers increased and gets better with a higher percentage of $70 \%$ mastery from the ideal learning completion. Results of the post-test for aplication content also experience an increase to be better, namely mastery level of $44,02 \%$ for the petroleum aplication content and 59,34\% for the polymers aplication content. However, althought it has experienced an increase, results of the post-test for this aplication content has not yet to be satisfying viewed from the aspect of its completion of students learning.

\section{Results of Calculation of n-Gain of Every Content Components}

The next analysis was performed againts ngain for each content components of chemistry to see in detail the contents in which the mastery has increased or the contrary. Figure 2 shows the percentage of pre-service teachers with certain n-gain criteria for the component of petrolium basic concept. The highest percentage of n-gain in the increased criteria of moderate, in total of $38,89 \%$, amounting to $33,33 \%$ preservice chemistry teachers did not experience an increased in the mastery of this content. There is pre-service teachers who have high $\mathrm{n}$ gain amounting to $27,78 \%$. This is needed to be looked over again the fact that there was no group of increase dominantly among high criterias, moderate and constant. This may be cause by the number of problems in this component were only four, thus the probability of the occurance of an increase in score would not be varied much.

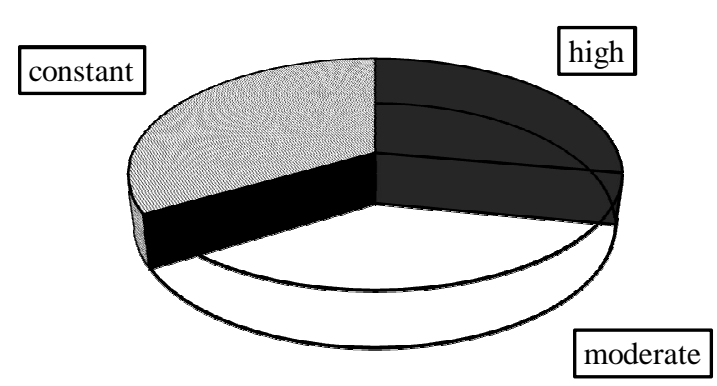

Figure 2. Percentage of n-Gain KDMB Component

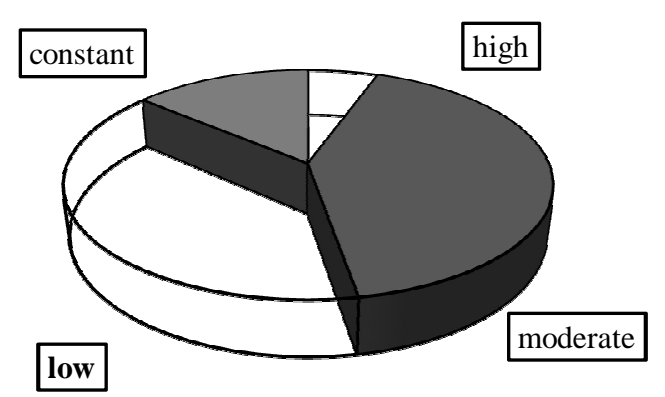

Figure 3. Percentage of n-Gain APMB Component

The next component is the content of petrolium aplication in the field of automotive. The number of items in this component were amounting to 15 problems with the content of aplication of fuel, solar and lubricant. There were four criterias of increase, starting from stable, low, fair and high. The highest percentage in the criteria of fair, was in total of 41 , $38 \%$. Only a small number of students who has high $\mathrm{N}$-gain, amounting to $5,56 \%$. As for the 
low increase criteria amounting to $38,89 \%$. The remaining is amounting to $13,89 \%$ students have $\mathrm{N}$-gain stable. This means that those students did not experience an increase in the mastery of petrolium aplication content in the field of automotive.

Figure 4 shows the percentage of students with $\mathrm{N}$-gain in particular for basic concept content of polymers. The largest percenttage increase in the basic concepts of polymer components was in the criteria of fair, amounting to $44.44 \%$, The low criteria has the smallest percentage of $13.89 \%$. A total of $16.67 \%$ of the students have n-gain in the criteria fair. The percentage increases in the low criteria are relatively smaller than other criteria, only $13,89 \%$. If viewed from the distribution of the percenttage increase in gain scores criteria, then this component the mastery level of students is better than other components of content.

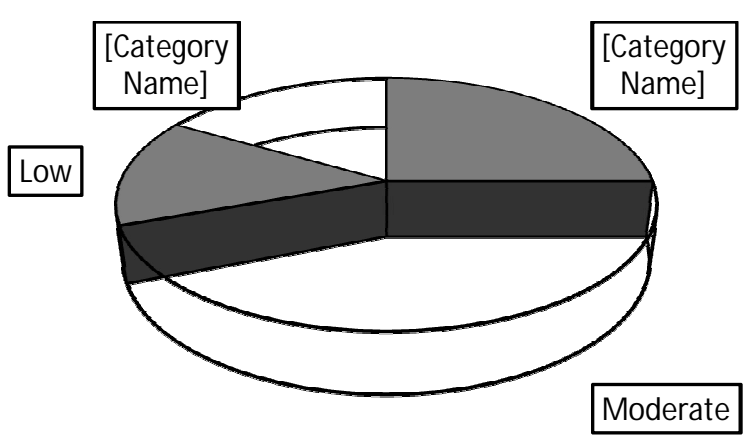

Figure 4. Percentage of n-Gain KDP Component

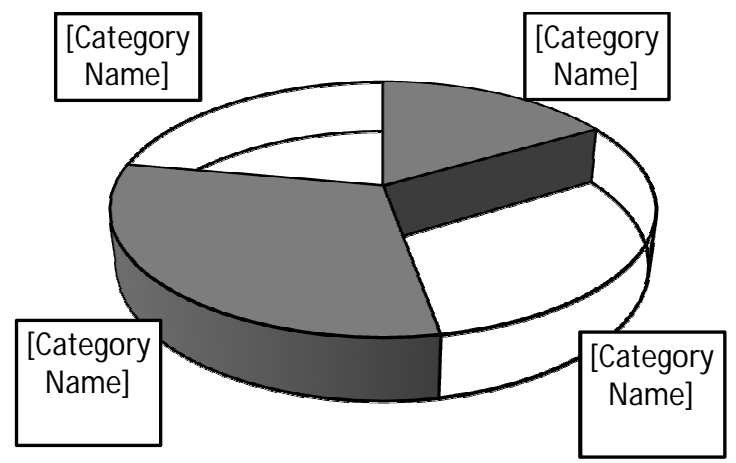

Figure 5. Percentage of n-Gain APP Component

The last component studied was polymers aplication content in the field of automo- tive. There are were 11 problem items, including rubber vulcanization content, nature and plastics grouping and the use of rubber and plastics in the field of automotive. Based on Figure 5 , the number of percentage of students with low mastery improvement and the students with moderate criteria were the same, in total of $30,56 \%$. Amounting to $16,67 \%$ students in the high improvement criteria and 22, 22\% students did not experience an increase of understanding in the component of petroleum aplication in the field of automotive.

\section{Discussion}

\section{The Effectiveness of Collaborative Learning}

Findings from this study indicate that the setting of collaborative learning based on problem-solving process is effective in increasing mastery of chemistry content of vocational context of preservice chemistry teachers. This is in line with the results of a research carried out by Warfa et al (2014:845), which concluded that with the collaborative learning, problem solving scientific results become better than the results of problem solving of the same content but done individually. Results of another study by Widjajanti and Wahyudin (2011:401) concludes that collaborative learning increases problem-solving skills that result in the increased of confidence of students towards mathematics. Constructivism paradigm supports the fact that knowledge should be constructed by students so that the level of understanding and retention of knowledge owned will be better.

Collaborative learning involves interaction among preservice teachers to exchange ideas, listen to each other, accept each other's' ideas and make decisions together. It gives a wider opportunity for them to develop reasoning. Research results carried out by Warfa et al (2014:846) concludes that the involvement of students in collaborative learning can provide a better mechanism for constructing scientific explanation. In collaborative learning, ideas from friends can broaden the extent of understanding possessed by students individually as well as to detect early if individuals may have a different conception of an alternative to a con- 
tent being or have been studied previously. Thus, preservice teachers will be richer in knowledge to develop a better scientific explanation.

Moreover, with the demands of high activity in collaborative learning, it makes preservice teachers more involved actively to construct knowledge. Preservice teachers who are actively exchanging ideas, debate and negotiate ideas in the group pointed to shows fact that collaborative learning increases students' interest in learning. This positive attitude is the case which will drive the process of knowledge construction goes well and the retention of knowledge remained relatively longer This is supported by several studies that concluded that the interests and attitudes of students towards sience learning becomes variables that have a big impact on the success of learning (Puyate 2008; Assaraf and Even, 2011; Adodo \& Gbore, 2012; and Juris'evic 'et al, 2012).

\section{Chemistry Content Knowledge of Petroleum and Polymer}

Knowledge of chemistry content is essentially knowledge of concepts, facts, principles, or laws in the disciplines of chemistry. In this study, based on the nature of knowledge, knowledge of content can be divided into basic knowledge and knowledge of applications in the automotive field. The results show that student knowledge about the basic concepts of petroleum and polymers gets better than the application of knowledge. Low mastery of presservice chemistry teachers for the content aplication of this is similar to several studies that concluded that most of the chemistry teacher has limitations in understanding the subject matter, with the main weakness in the understanding of chemistry application content and make chemistry theory applicable to the real world (Ozden, 2008; Ghazi et al, 2013).

The percentage of mastery of content basic knowledge exceeds $70 \%$, but for the application of knowledge is still less than $50 \%$ of the ideal learning completeness. This distinction is made possible by a variety of factors, both from within and factors outside the stu- dent. Here are some factors suspected to be a factor causing low mastery of knowledge of petroleum and polymer applications in the automotive field.

Factors of chemistry content characteristic. Characteristics of chemistry content is one of the external factors. Chemistry is a branch of science where the topics in general is related or based on the structure of the material that is often be difficulties for many students (Sirhan, 2007:2). Abstractness the nature of chemistry requires high level thinking skills in understanding it. Within the scope of chemistry, petroleum and polymer content are included in the knowledge that is complex and involves many knowledge prerequisites. An understanding of the petroleum material involving prerequisite knowledge such as the structure and nature of the hydrocarbons, burning of hydrocarbons as well as the principles of distillation. The prerequisite knowledge to learn more and more complex polymers. Understanding prerequisites that have gone unresolved can interfere with the ability of students to understand a higher concept. For example, students will have difficulty in explaining the effect of mixing premium and pertamax if his understanding of the nature and structure of octane and heptane combustion is incomplete or low. This is line of research results carried out by De Jong (2008: 142) states that the difficulties experienced in understanding the chemistry experienced by students of preservice teachers rooted from the shortcomings and incomplete study in chemistry in high school.

Factors of learning difficulties. The next factor is the learning difficulties experienceed by students. Low reasoning abilities become a source of great difficulty. Learning chemistry that have been received by students, ranging from high school to college, teachers tend to use more teacher-centered learning approach such as lectures. This condition causes the students only used to receiving knowledge, not construct knowledge that the development of reasoning ability, especially in implementing higher-level thinking skills are still low. Several studies indicate that some of the problems 
found to be associated with the ability to master the content experienced by students of preservice teachers are sourced from conceptual difficulties (Ozden, 2008; De Jong, 2008 and Usak, 2009). Furthermore, Ozden (2008: 633) concludes that students of preservice teachers experience misconceptions and inaccuracies at the level of conceptual understanding. This is due to the difficulty to understand the relationships between concepts that are affected by the experience acquired previously.

Factor of experience. Experience possessed is closely related with preservice teacher comprehension. The more frequently person interact with a learning material then the ability to retain knowledge in general would be better. This is in line with research carried out by Justi \& van Driel (2005:214) that the overall experience of a content helps preservice teachers in applying knowledge of science possessed. The experience factor was also examined from the results of interview. Most of the preservice teachers stated that they have not been learn the content of petroleum and polymers in previous learning, both at the high school and college. There are only a few students who were told that the content was mentioned in high school when discussing macromolecules and limited to definition and classification of polymers.

Meanwhile, for petroleum content they said that they were only received material about what is produced from the fractionation of petroleum. Thus, petroleum and polymer content, especially in terms of its applications is a new thing so it takes a longer time and depth understanding for preservice teachers to be able to understand it well. Rohandi (2014:421), recommends a science learning that focuses on combining the knowledge of students, especially in presenting the science relevant to everyday life. This means that in order to understand the content of the chemistry in the context of automotive properly, then the students of preservice teachers should be given the opportunity to develop and combine knowledge of chemistry with specialized knowledge in the automotive, such as combustion engines or vehicle body painting.
Other experience factors can be sourced from the limited experience of preservice teachersin learning collaboratively in groups to solve problems. Students who are not accustomed to interacting with other people when learning will experience communication difficulties when confronted with a problem that must be solved together. This is supported by the study results carried out by Fahyuddin et al, 2015:43) suggests that students who are not familiar with tasks that can stimulate thinking skills through problem solving experience difficulty in learning new situations and use the principles of work in problem solve. Thus, to improve the mastery of content knowledge of prospective teachers through collaborative learning, students should be given as much as possible the experience to construct his knowledge rooted in the problems in real life, in this case related to the automotive field.

\section{CONCLUSION}

In general, the results showed that collaborative learning with problem-solving activity was effective to improve the mastery of knowledge of chemistry content of automotive context for preservice chemistry teachers. Content knowledge of preservice teachers to the basic concepts of petroleum and polymer is quite good. As for knowledge of petroleum and polymer applications in the automotive field, are still low. Some factors thought to be the cause of the low knowledge of the content of this application. These factors include; characteristics of content, learning difficulties, as well as experience factor.

\section{ACKNOWLEDGEMENT}

Thank you very much to the Directorate General of Higher Education who has provided scholarships of BPPS thereby facilitating the writing of this article as part of a research dissertation. Thank you for the editorial team of the Journal of Cakrawala Pendidikan who has been pleased to publish scientific papers. 


\section{BIBLIOGRAPHY}

Adodo, Sunday Olufemi \& Gbore, L. O. 2012. "Prediction of Attitude And Interest of Science Students of Different Ability on Their Academic Performance in Basic Science". International Journal of Psychology and Counselling, 4 (6), hlm. 6872.

Arrington, C.A, Hill, J.B., Radfar, R., Whisnant, D.M. dan Bass, C.G. 2008. "Peer Mentoring in the General Chemistry and Organic Chemistry Laboratories". Journal of Chemical Education, 85 (2), hlm. 278-290.

Assaraf, O. B.V. dan Even, C. 2011. "Positions Toward Science Studies in Medicine Among University Graduates of Medicine and the Teenaged Participants of the Medical Systems Study Program". Journal Science Education and Technology, 20, hlm.317-332.

Barkley, E.F., Cross, K.P. dan Major. C.H. 2005. Collaborative Learning Techniques. San Fransisco: Jossey-Bass.

Baumert, J., Kunter, M., Blum, W., Brunner, M., Voss, T., Jordan, A. 2010. "Teachers Mathematical Knowledge, Cognitive Activation in the Classroom and Student Progress". American Educational Research Journal, 47 (1), hlm. 133-180.

De Jong, Nobile. 2007. "Primary Teacher Knowledge of Science Concepts and Professional Development: Implications for a Case Study, Teaching Science". Journal of the Australian Science Teachers Association, 53 (2), hlm. 20-23.

Dolfing, R., Bulte, Astrid M.W., Pilot, A. \& Vermunt, J.D. 2012. "Domain-Specific Expertise of Chemistry Teachers on Context-Based Education About Macro-Micro Thinking in Structure-Property Rela- tions". Research in Science Education, 42 (3), hlm. 567-588.

DITPSMK. 2014. "Spektrum Keahlian Sekolah Menengah Kejuruan”. www.psmk.kemdikbud.go.id/data/. Diunduh tanggal 7 Mei 2014.

Fahyuddin, Liliasari, Sabandar, J. dan Martoprawiro, M.A. 2015. "Perbandingan Metode Kolaborasi dengan Contoh Tugas dan Belajar Individual dalam Pengembangan Kemampuan Pemecahan Masalah". Cakrawala Pendidikan, XXXIV (1), hlm. 34-46.

Faraday, S., Overton, C., \& Cooper, S. 2012. "Effective Teaching and Learning in Vocational Education. London: LSN. http://policyconsortium.co.uk/wp-content/uploads/2012/01/110052RP_effective-VET final-report1.pdf. Diunduh Tanggal 3 Maret 2013.

Juris`evic, Mojca.......... a Margareta Vrtac`nik, b Marek Kwiatkowskic dan Nataša Grosd. 2012. "The Interplay of Students' Motivational Orientations, Achievements And Their Perception of Learning Within The Their Chemistry Hands-On Approach to Visible Spectrometry". Chemistry Education Research Practice, 13, 237-247.

Justi, Rosaria., dan van Driel, Jan. 2005. "A Case Study of the Development of a Beginning Chemistry Teacher's Knowledge about Models and Modelling”. Research in Science Education, 35, hlm. 197-219.

Kapyla, M., Heikkenen, JP. Dan Asunta, T. 2009. "Influence of Content Knowledge on Pedagogical Content Knowledge: The Case Teaching Photosynthesis and Plant Growth". International Journal of Science Education, 31(10), hlm. 1395-1415. 
Karaman, Ayhan. 2012. "The Place of Pedagogical Content Knowledge in Teacher Education". Atlas Journal of Science Education, 2 (1), hlm. 56-60.

Khasawneh, Samer A., Olimat, Qablan, AbuTineh. 2008. "Measuring the Perceptions of Vocational Education Students Regarding the Application of National Vocational Teacher Standard in the Classrooms: The Key to Human Resource Education in Jordan”. IJAES, 2 (1), hlm. 24-37.

NSTA.2003. Standard for Science Teacher Preparation.

Ozden, Mustafa. 2008. "The Effect of Content Knowledge on Pedagogical Content Knowledge: The Case of Teaching Phases of Matters". Educational Science: Theory \& Practice, 8 (2), hlm. 633-645.

Puyate, S.T. 2008. "Constraints to The Effective Implementation of Vocational Education Program in Private Secondary Schools in Port Harcourt Local Government Area". Asia-Pasific Journal of Cooperative Education, 9(1), hlm. 57-71.

Rohaan, E.J, Taconis, R., dan Jochems, W.M.G. 2009. "Measuring teachers' pedagogical content knowledge in primary technology education". Research in Science \& Technological Education, 27(3), hlm. 27-338.

Rohandi. 2014. "Teacher's Experiences in Incorporating Student's Funds of Know- ledge to Promote the Leader of Science". Cakrawala Pendidikan, Th. XXXIII, No. 3, hlm. 421-433.

Sirhan, Ghassan. 2007. "Learning Difficulties in Chemistry: An Overview". Journal of Turkish Science Education, 4 (2), hlm.112.

Usak, Muhammet, Ozden, Mustafa dan Eilks, Ingo. .... "Case Study of Beginning Science Teachers' Subject Matter (SMK) and Pedagogical Content Knowledge (PCK) of Teaching Chemical Reaction in Turkey". European Journal of Teacher Education, 34 (4), hlm. 407-429.

Warfa, Abdi-Rizak., Roehrig, Gillian., Schneiderc, Jamie., dan Nyachwayad. 2014. "Collaborative Discourse and the Modeling of Solution Chemistry with Magnetic 3D Physical Models - Impact and Characterization". Chemical Education Research. Practice, 15, hlm. 835-848.

Widjajanti, D.B dan Wahyudin. 2011. "Mengembangkan Kemampuan Pemecahan Masalah dan Belief Calon Guru Matematika Melalui Strategi Perkuliahan Kolaboratif". Cakrawala Pendidikan, XXX (3), hlm. 401-415.

Wilson, R.F., Pan, Wei dan Schumsky. 2012. "Recalculating of the Critical Values for Lawshe's Content Validity Ratio". Measurement and Evaluation in Counseling and Development, 45 (3), hlm. 197-210. 